\title{
Description of ABO-Rhesus Blood Group and Fingerprint Patterns Students D-3 Teknologi Transfusi Darah of STIKES Guna Bangsa Yogyakarta
} Gambaran Golongan Darah ABO-Rhesus dan Pola Sidik Jari Pada Mahasiswa Program Studi D-3 Teknologi Transfusi Darah STIKES Guna Bangsa Yogyakarta

St. Raihanun, Diani Mentari, Meyta Wulandari, Relita Pebrina

\begin{abstract}
Human identification is the recognition of individuals based on some physical characteristics that are unique to individuals. Fingerprints are constant, individuality and form the most reliable criteria for identification. ABO-Rhesus Blood group is also one method used to identify someone, because blood type is inheritance. This research was conducted to see the description of ABO-Rhesus blood group and fingerprint patterns students D-3 Teknologi Transfusi Darah STIKES Guna Bangsa Yogyakarta. In this study using quantitative cross sectional descriptive research and blood group samples were taken using the slide method and fingerprint patterns were taken using the fingerprint method. In this study there were 78 samples, 58 females $(74.36 \%)$ and 20 males (25.64\%). The ABO blood group that is dominant is blood type $\mathrm{O}(35.90 \%)$, followed by blood group $\mathrm{A}(29.49 \%), \mathrm{B}(28.21 \%)$, and $\mathrm{AB}(6.41 \%)$. The dominant Rhesus blood type is the positive Rhesus blood group. The percentage of fingerprint patterns in this study was loop $61.03 \%$, whorl $37.56 \%$, and arch $1.41 \%$. The characteristics of the right and left hand fingerprint patterns have the same percentage of arch fingerprint patterns found on the index finger. Whorl fingerprint patterns are found on the ring finger. Loop fingerprint patterns are found on the little finger.
\end{abstract}

Keywords: Fingerprint, ABO-Rhesus Blood Group, Identification.

Afiliasi Penulis

Prodi D3 Teknologi Transfusi Darah STIKes Guna Bangsa

Yogyakarta

Korespondensi kepada

D. Mentari

dianimentari@gmail.com 


\section{Intisari}

dentifikasi manusia adalah pengakuan individu berdasarkan beberapa karakteristik fisik yang khas pada individu. Sidik jari bersifat konstan, individualitas dan membentuk kriteria yang paling dapat diandalkan untuk identifikasi. Golongan darah ABO-Rhesus juga salah satu metode yang digunakan untuk mengidentifikasi seseorang, karena golongan darah merupakan sifat yang inheritance.Penelitian ini dilakukan untuk melihat gambaran golongan darah ABO-Rhesus dan pola sidik jari pada mahasiswa D-3 Teknologi Transfusi Darah STIKES Guna Bangsa Yogyakarta. Pada penelitian ini menggunakan penelitian deskriptif cross sectional secara kuantitatif dan sampel golongan darah diambil menggunakan metode slide dan pola sidik jari diambil menggunakan metode cap jari.Pada penelitian ini terdapat 78 sampel, perempuan 58 (74,36\%) dan laki-laki 20 (25,64\%). Golongan darah ABO yang dominan adalah golongan darah $\mathrm{O}(35,90 \%)$, diikuti oleh golongan darah A (29,49\%), B (28,21\%), dan AB $(6,41 \%)$. Golongan darah Rhesus yang dominan adalah golongan darah Rhesus positif. Persentase pola sidik jari pada penelitian ini adalah loop $61,03 \%$, whorl $37,56 \%$, dan arch $1,41 \%$. Karakteristik pola sidik jari tangan kanan dan tangan kiri memiliki persentase yang sama yaitu pola sidik jari arch banyak ditemukan pada jari telunjuk. Pola sidik jari whorl banyak ditemukan pada jari manis. Pola sidik jari loop banyak ditemukan pada jari kelingking.

Kata kunci: Sidik Jari, Golongan Darah ABO-Rhesus, Identifikasi

\section{Pendahuluan}

Identifikasi manusia adalah pengakuan individu berdasarkan beberapa karakteristik fisik yang khas pada individu. Identikasi melibatkan karakteristik fungsional dan patologis yang mendefinisikan tiap individu. Identifikasi manusia diperlukan untuk alasan pribadi, sosial, dan hukum (Limson dan Julian, 2004). Metode identifikasi yang digunakan adalah pola sidik jari, tulisan tangan, anatomi gigi, sidik jari DNA, diferensiansi oleh golongan darah, penentuan jenis kelamin. Selain itu, metode yang berkembang adalah identifikasi individu dengan cetakan bibir (Eboh, 2013; Eboh dan Nwajei, 2012).

Sidik jari bersifat konstan, individualistis dan membentuk kriteria yang paling dapat diandalkan untuk identifikasi (Prateek dan Keerthi, 2010). Sidik jari adalah kesan garis-garis melengkung pada kulit dari semua bagian jari. Garis lengkung adalah bagian epidermis yang diangkat dari jari-jari atau pada kulit telapak tangan (palmar) dan telapak kaki (plantar), yang terdiri dari satu atau lebih dari satu garis melengkung (Aarushi dkk, 2016).

Pola sidik jari ditentukan secara genotip dan tetap tidak berubah sejak lahir sampai mati (Vij, 2005). Pola sidik jari terbentuk selama 3 dan 4 bulan kehidupan janin (Cummins dan Kennedy,
1940). Pola sidik jari adalah salah satu bentuk dari keanekaragaman genetik yang ada pada tiap manusia. Ilmu yang mempelajari sidik jari disebut dermatoglyphics. Pillay (2009) mengunkapkan bahwa pola sidik jari diklasifikasikan ke dalam empat kelompok besar: Loop, Whorl,Arch dan Komposit. Pada penelitian Manju dkk (2016), Arch adalah pola yang sederhana dan juga yang paling langka (sekitar 5,16\%). Loopadalah pola yang paling umum yaitu, sekitar 59,22\%.

Selain sidik jari, golongan darah dapat digunakan juga sebagai identifikasi. Karl Landsteiner adalah ilmuan yang menemukan sistem pengelompokan golongan darah pada tahun 1901. Sampai saat ini, ada 36 kelompok golongan darah yang telah teridentifikasi dengan berbagai variasi dalam pola distribusi ras manusia(Anonim, 2018). Sistem golongan darah $A B O$ dan Rhesus adalah kelompok golongan darah yang berperan penting dalam tujuan klinis. Sistem $A B O$ selanjutnya diklasifikasikan lagi menjadi $A, B, A B$, dan $O$ terhadap antigen yang sesuai dalam sel darah merah, sedangkan antigen $D$ adalah dasar dari klasifikasi sistem Rhesus menjadi Rhesus positif dan Rhesus negatif (Dean, 2005).

Masalah utama yang ingin dibahas dalam penelitian ini adalah untuk mengetahui gambaran 
golongan darah $\mathrm{ABO}-\mathrm{Rhesus} \mathrm{dan} \mathrm{pola} \mathrm{sidik} \mathrm{jari}$ pada mahasiswa D-3 Teknologi Transfusi Darah STIKES Guna Bangsa Yogyakarta. Namun, penelitian yang berfokus menganalisis golongan darah $\mathrm{ABO}$ Rhesus dan pola sidik jari pada mahasiswa D-3 Teknologi Transfusi Darah STIKES Guna Bangsa Yogyakarta sejauh ini belum dilakukan dalam populasi ini.

Oleh sebab itu, penelitian ini dilakukan untuk melihat keanekaragaman genetik pada mahasiswa D-3 Teknologi Transfusi Darah STIKES Guna Bangsa Yogyakarta berdasarkan golongan darah ABORhesus dan pola sidik jari.

\section{Metode}

Penelitian ini menggunakan jenis penelitian deskriptif cross sectional secara kuantitatif. Penelitian ini dilakukan pada bulan Juni 2019 di laboratorium Transfusi Darah, untuk mengambil sampel darah dan pola sidik jari.

\section{Alat}

Alat-alat yang digunakan dalam penelitian ini adalah autoklik blood lancet, kaca pembesar, kaca persegi, bold marker, dan bantalan tinta.

\section{Bahan}

Bahan yang digunakan untuk penelitian ini adalah kartu golongan darah, serum (anti-A, anti-B, anti-AB, dan anti-D), blood lancet, alkohol swab $70 \%$, tusuk gigi, tissue, dan kertas HVS A4.

\section{Prosedur penelitian}

Penelitian ini dilaksanakan dalam beberapa tahap. Pertama, tahap persiapan yaitu mengurus surat izin penelitian dan persetujuan dari sampel. Kedua, pengambilan sampel darah dan pola sidik jari. Ketiga, tahap pengamatan yaitu mengidentifkasi golongan darah ABO-Rhesus metode slide dan pola sidik jari klasifikasi Galton, dan data yang diperoleh dianalisis menggunakan Microsoft Office Excel 2016 dan disajikan dalam bentuk tabel, presentase, narasi maupun distribusi frekuensi.

Identifkasi golongan darah ABO-Rhesus dilakukan dengan cara jari manis/tengah sampel didesinfeksi menggunakan alkohol swab 70\% dan ditusuk menggunkan blood lancet steril. Darah diteteskan pada setiap kolom yang ada pada kartu golongan darah dan dicampurkan dengan serum
(anti-A, anti-B, anti-AB, dan anti-D). Golongan darah ditentukan berdasarkan ada tidaknya aglutinasi.

Identifikasi pola sidik jari dilakukan dengan cara setiap jari sampel diletakkan pada bantalan tinta dan ditempelkan pada kertas lembar data penelitian yang telah disediakan sehingga terbentuk pola sidik jari yang jelas. Pola sidik jari yang terbentuk dianalisis berdasarkan klasifikasi Galton. Pola arch memiliki ciri unik yaitu tidak ada delta dalam pola lengkungannya. Pola whorl adalah pola sidik jari yang terlihat seperti pusaran, memiliki sulur yang melingkari core dan memiliki dua atau lebih delta. Pola loop adalah pola sidik jari yang memiliki satu atau beberapa sulur dan satu delta.

\section{Hasil \& Pembahasan}

Hasil penelitian ini diperoleh 78 sampel yang dijumpai pada mahasiswa program studi D-3 Teknologi Transfusi Darah STIKES Guna Bangsa Yogyakarta dengan jumlah sampel perempuan 58 $(74,36 \%)$ dan laki-laki 20 (25,64\%) (Tabel 1). Hal ini sesuai dengan penelitian yang dilakukan oleh Eboh (2013) pada mahasiswa Delta State University, Nigeria yang menyatakan bahwa jumlah partisipan perempuan lebih banyak dibandingkan laki-laki.

Hasil analisis golongan darah $\mathrm{ABO}$ menunjukkan bahwa golongan darah $O$ dominan (35,90\%), diikuti golongan darah A $(29,49 \%)$, golongan darah B $(28,21 \%)$, dan golongan darah $A B(6,41 \%)$ (Tabel 2$)$. Hasil penelitian ini sama dengan penelitian yang dilakukan Eboh (2013) menunjukkan bahwa golongan darah yang dominan adalah golongan darah O $(55,9 \%)$, diikuti golongan darah A $(22,4 \%)$, golongan darah $B(20,4 \%)$ dan kemudian golongan darah $A B(1,2 \%)$. Hal yang berbeda terjadi pada penelitian Manju dkk (2016), bahwa golongan darah yang dominan adalah golongan darah $O$ sebanyak 36,28\%, golongan darah B sebanyak $33,48 \%$ yang diikuti oleh golongan darah $A$

\begin{tabular}{|c|c|c|}
\hline Jenis Kelamin & Jumlah & Frekuensi \\
\hline Laki-laki & 20 & $25,64 \%$ \\
\hline Perempuan & 58 & $74,36 \%$ \\
\hline Total & 78 & $100,00 \%$ \\
\hline
\end{tabular}


Tabel 2 | Jumlah Golongan Darah ABO Berdasarkan Jenis Kelamin

Frekuensi Golongan Darah

Total

\begin{tabular}{rccccc} 
Jenis Kelamin & A & B & O & AB & \\
\cline { 2 - 5 } Laki-laki & 16 & 17 & 20 & 5 & 58 \\
& $20,51 \%$ & $21,79 \%$ & $25,64 \%$ & $6,41 \%$ & $74,36 \%$ \\
Perempuan & 7 & 5 & 8 & 0 & 20 \\
\hline Total & $8,97 \%$ & $6,41 \%$ & $10,26 \%$ & $0,00 \%$ & $25,64 \%$ \\
\hline & 23 & 22 & 28 & 5 & 78 \\
& $29,49 \%$ & $28,21 \%$ & $35,90 \%$ & $6,41 \%$ & $100,00 \%$
\end{tabular}

sebanyak $20,78 \%$ dan golongan darah $A B$ sebanyak 9,47\%.

Adapun frekuensi golongan darah $A B O$ pada mahasiswa program studi D-3 Teknologi Transfusi Darah STIKES Guna Bangsa Yogyakarta berdasarkan jenis kelamin dapat dilihat pada Tabel 2. Pada Tabel 2golongan darah A laki-laki sebanyak 8,98\% sedangkan perempuan $20,51 \%$. Golongan darah B laki-laki sebanyak $6,41 \%$ sedangkan perempuan $21,79 \%$. Golongan darah O laki-laki 10,26\% sedangkan perempuan $25,64 \%$. Golongan darah AB laki-laki sebanyak $0 \%$ sedangkan perempuan sebanyak 6,41\%.

Golongan darah Rhesus yang ditemukan pada penelitian ini adalah Rhesus positif sedangkan untuk Rhesus negatif tidak ditemukan. Golongan darah Rhesus populasi ini paling banyak pada jenis kelamin perempuan dibandingkan laki-laki. Pada Gambar 1 menunjukkan golongan darah Rhesus positif laki-laki sebanyak $25,64 \%$ sedangkan perempuan $74,36 \%$. Hal ini sama seperti penelitian yang dilakukan Eboh (2013) bahwa golongan darah Rhesus lebih banyak pada perempuan dibandingkan laki-laki, dan golongan darah Rhesus positif adalah golongan darah Rhesus yang dominan (97,75\%). Pada penelitiannya golongan darah Rhesus positif laki-laki sebanyak 48,43\% sedangkan perempuan 51,57\%. Golongan darah Rhesus negatif laki-laki sebanyak $36,36 \%$ sedangkan perempuan $63,64 \%$.

Persentase jumlah pemilik Rhesus negatif berbeda-beda antar kelompok ras. Tidak adanya

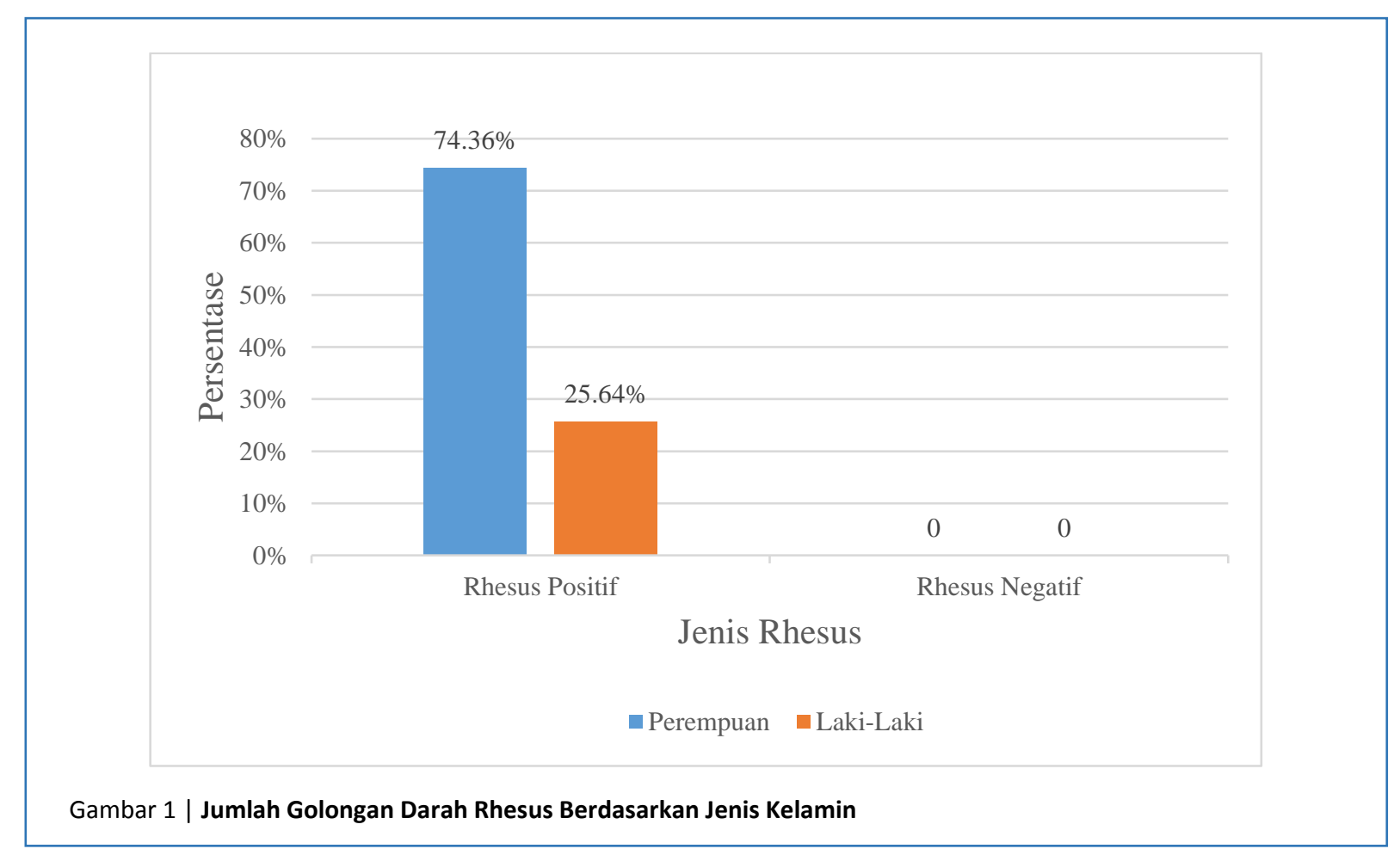


Tabel 3 | Jumlah Pola Sidik Jari

\begin{tabular}{ccc} 
Pola Sidik Jari & Jumlah & Frekuensi \\
\hline Arch & 11 & $1,41 \%$ \\
Whorl & 293 & $37,56 \%$ \\
Loop & 476 & $61,03 \%$ \\
Total & 780 & $100,00 \%$
\end{tabular}

Rhesus negatif sangat berkaitan dengan ras. Pada ras berkulit putih (warga Eropa, Amerika, dan Australia), jumlah pemilik rhesus negatif sekitar 15$18 \%$. Sedangkan pada ras Asia, persentase pemilik Rhesus negatif jauh lebih kecil. Secara umum golongan darah Rhesus paling banyak ditemukan di Indonesia adalah Rhesus positif, hanya kurang dari $1 \%$ atau sekita 1,2 juta orang yang memiliki Rhesus negatif (Anonim, 2015). Persentasenya yang sangat kecil, sehingga pemilik Rhesus negatif pada populasi ini tidak ditemukan.

Tabel 3 menunjukkan jumlah pola sidik jari dari total 78 sampel pada sepuluh jari yaitu 780 . Pola sidik jari paling banyak pada penelitian ini adalah pola sidik jari loop sebanyak 476 (61,03\%), whorl sebanyak 293 (37,56\%), dan arch sebanyak 11 $(1,41 \%)$. Hal ini sama dengan penelitian yang dilakukan oleh Manju dkk (2016), bahwa pola sidik jari yang dominan adalah pola sidik jari loop
Tabel 4 | Jumlah Pola Sidik Jari Berdasarkan Jenis Kelamin

\begin{tabular}{ccccc}
\multirow{2}{*}{$\begin{array}{c}\text { Jenis } \\
\text { Kelamin }\end{array}$} & \multicolumn{3}{c}{ Frekuensi Pola Sidik Jari } & \multirow{2}{*}{ Total } \\
\cline { 2 - 4 } & Arch & Whorl & Loop & \\
\hline \multirow{2}{*}{ Perempuan } & 10 & 218 & 352 & 580 \\
& $1,28 \%$ & $27,95 \%$ & $45,13 \%$ & $74,36 \%$ \\
\hline \multirow{2}{*}{ Laki-laki } & 1 & 75 & 124 & 200 \\
& $0,13 \%$ & $9,62 \%$ & $15,90 \%$ & $25,64 \%$ \\
\hline
\end{tabular}

sebanyak 5502 (59,22\%) kemudian diikuti pola sidk jari whorl sebanyak 3309 (35,62\%) dan arch sebanyak 479 (5,16\%). Hasil penelitian ini sesuai dengan teori klasifikasi Galton yang menyatakan bahwa pola sidik jari yang paling umum ditemukan adalah loop, yang diikuti pola whorl dan arch yang paling langka (Hutchins, 2004).

Jika dipisahkan berdasarkan jenis kelamin, dapat dilihat bahwa perempuan memiliki persentase yang lebih tinggi dibandingkan laki-laki seperti yang terlihat pada Tabel 4 yaitu pada pola sidik jari loop perempuan sebanyak 45,13\% sedangkan laki-laki sebanyak $15,90 \%$. Pola sidik jari whorl perempuan sebanyak 27,95\% sedangkan laki-laki sebanyak 9,62\%. Pola sidik jari arch perempuan sebanyak $1,28 \%$ dan laki-laki sebanyak $0,13 \%$. Hal ini berbeda dengan penelitian yang dilakukan oleh Prateek dan Keerthi (2010) disetiap pola sidik jarinya memiliki persentase yang

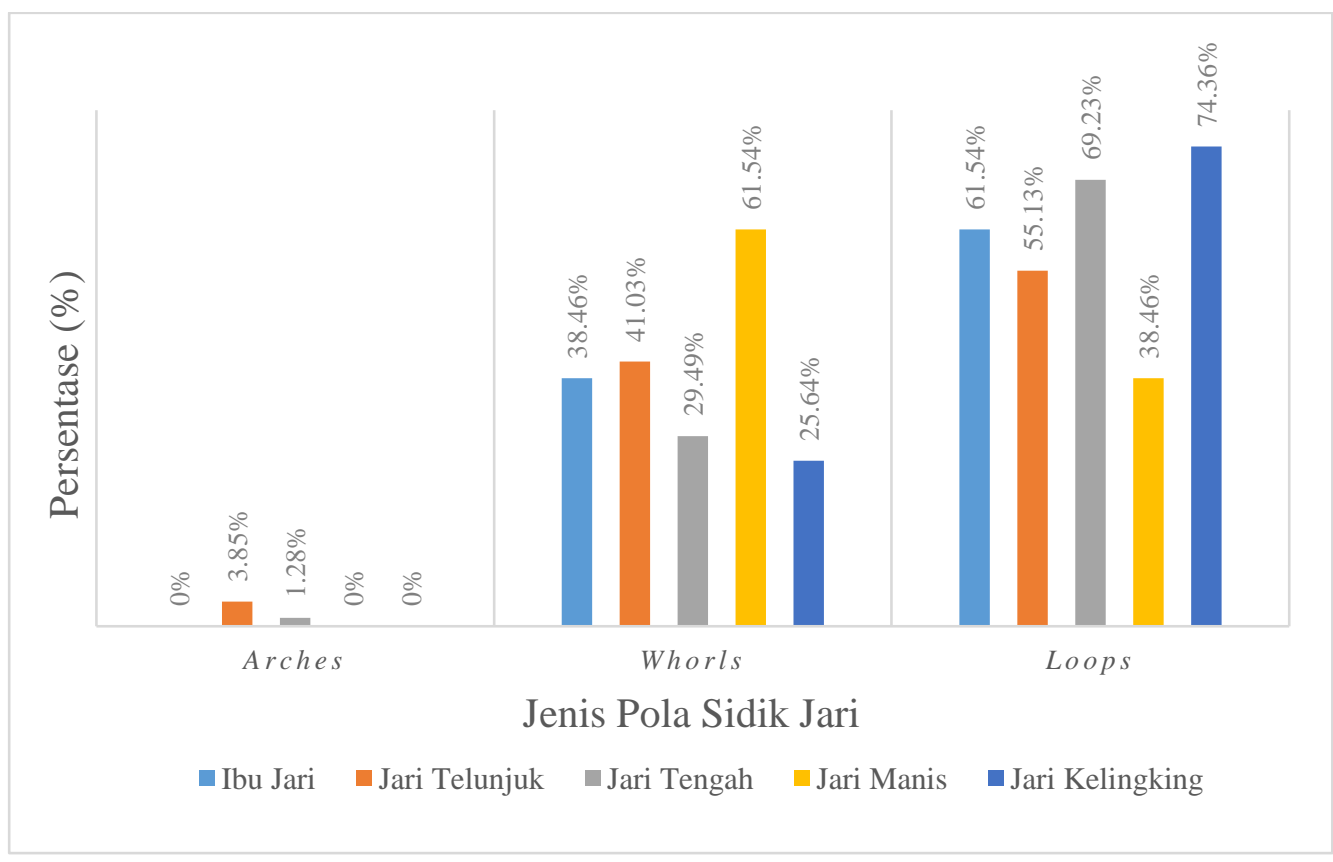

Gambar 2 | Karakteristik Pola Sidik Jari Pada Tangan Kanan 


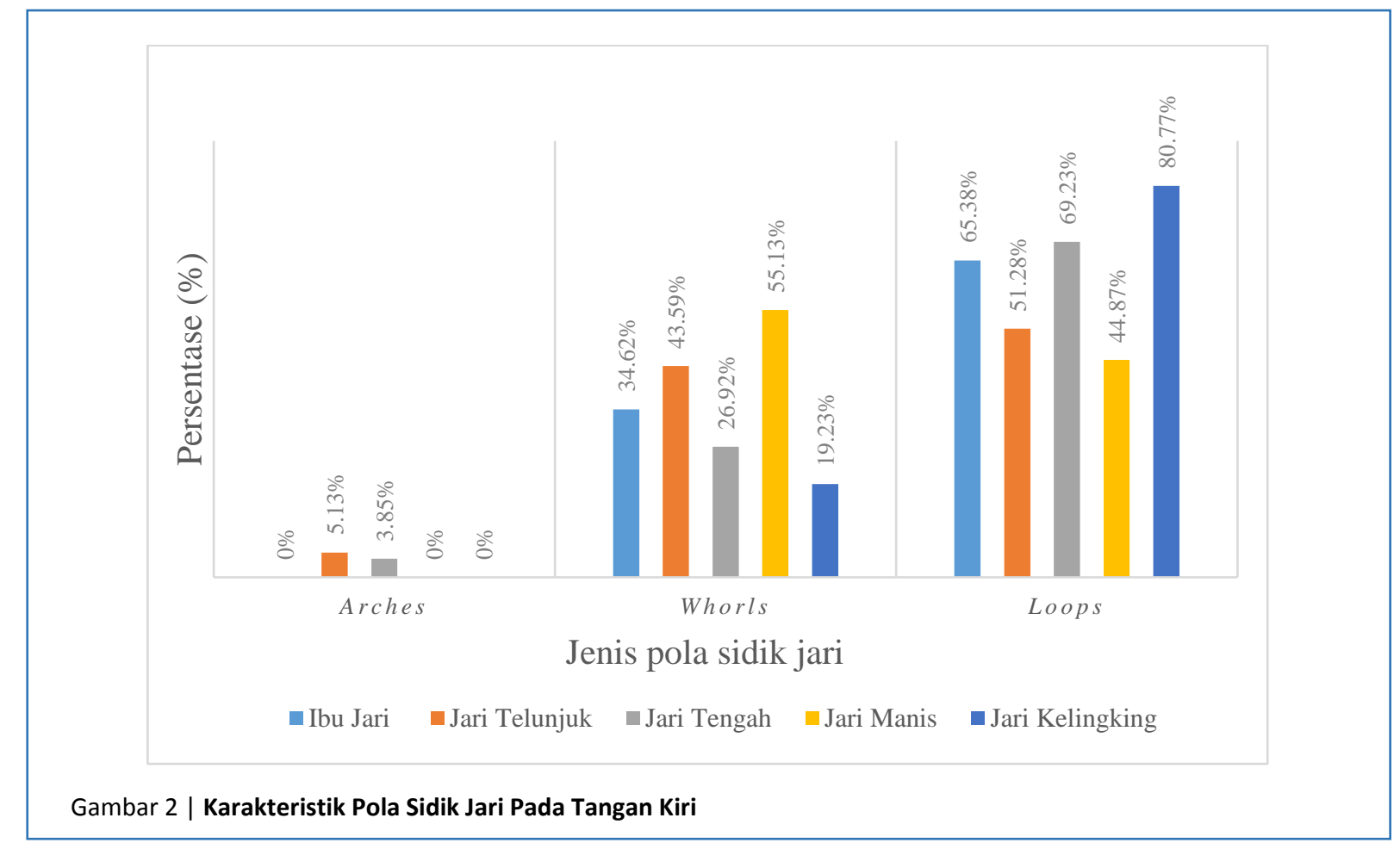

bervariasi yaitu perempuan memiliki persentase loop dan arch yang lebih tinggi, sementara laki-laki memiliki persentase yang tinggi pada pola whorl.

Penelitian ini juga membedakan karakteristik pola sidik jari pada tangan kanan dan tangan kiri. Hasil penelitian karakteristik pola sidik jari tangan kanan menunjukkan pola sidik jari arch tertinggi terdapat pada jari telunjuk sebanyak 3,85\%, diikuti jari tengah sebanyak $1,28 \%$, dan pada ibu jari, jari manis serta jari kelingking tidak ditemukan pola sidik jari arch. Pola sidik jari whorl paling banyak terdapat pada jari manis sebanyak $61,54 \%$, dan paling sedikit terdapat pada jari kelingking $25,64 \%$. Pola sidik jari loop paling banyak terdapat pada jari kelingking sebanyak $74,36 \%$, dan plaing sedikit terdapat pada jari manis $38,46 \%$ (Gambar 2).

Hasil penelitian karakteristik pola sidik jari tangan kiri menunjukkan pola sidik jari arch tertinggi terdapat pada jari telunjuk sebanyak $5,13 \%$, diikuti jari tengah sebanyak 3,85\%, dan pada ibu jari, jari manis serta jari kelingking tidak ditemukan pola sidik jari arch. Pola sidik jari whorl paling banyak terdapat pada jari manis sebanyak $55,12 \%$, dan terendah ada pada jari kelingking $19,23 \%$. Pola sidik jari loop paling banyak terdapat pada jari kelingking sebanyak $80,77 \%$, dan terendah pada jari manis $44,87 \%$ (Gambar 3 ).
Hal yang sama terjadi pada penelitian Manju dkk (2016), bahwa pada pola sidik jari tangan kanan pola sidik jari arch tertinggi terdapat pada jari telunjuk dan terendah pada jari kelingking. Pola sidik jari whorl paling banyak terdapat pada pada jari manis, dan terendah ada pada jari kelingking. Pola sidik jari loop paling banyak terdapat pada jari kelingking, dan terendah pada jari manis.Hal yang sama terjadi pada tangan kiri, bahwa pola sidik jari arch tertinggi terdapat pada jari telunjuk, dan terendah pada jari kelingking. Pola sidik jari whorl paling banyak terdapat pada pada jari manis, dan terendah ada pada jari tengah. Pola sidik jari loop paling banyak terdapat pada jari kelingking, dan terendah pada jari manis. Berdasarkan penelitian ini dan Manju dkk dapat ditarik kesimpulan bahwa pola sidik jari arch banyak ditemukan pada jari telunjuk. Pola sidik jari whorl banyak ditemukan pada jari manis. Pola sidik jari loop banyak ditemukan pada jari kelingking.

Penelitian ini hanya terbatas pada keanekaragaman genetik pada golongan darah ABO-Rhesus dan pola sidik jari, sehingga belum dapat dilihat apakah golongan darah ABO-Rhesus berhubungan dengan timbulnya pola yang khas pada tiap-tiap individu. 


\section{Kesimpulan}

Kesimpulan dari penelitian ini adalah golongan darah $A B O$ pada mahasiswa program studi D-3 Teknologi Transfusi Darah STIKES Guna Bangsa Yogyakarta berdasarkan jenis kelamin perempuan memiliki persentase tertinggi pada golongan darah O 25,64\% dan laki-laki tertinggi pada golongan darah 010,26\%. Golongan darah Rhesus positif pada perempuan sebanyak $74,36 \%$, dan laki-laki sebanyak 25,64\%. Golongan darah Rhesus negatif tidak ditemukan pada populasi ini.

Pola sidik jari yang tertinggi sampai yang terendah berturut-turut adalah pola loop (61,03\%), whorl (37,56\%), dan arch (1,41\%). Jika dipisahkan berdasarkan jenis kelamin, pada perempuan terdapat pola loop sebanyak 45,13\%, whorl 27,95\%, dan arch 1,28\%. Pada laki-laki terdapat pola loop sebanyak 15,90\%, whorl 9,62\%, dan arch $0,13 \%$. Berdasarkan tangan kanan dan kiri yaitu pola sidik jari arch banyak ditemukan pada jari telunjuk. Pola sidik jari whorl banyak ditemukan pada jari manis. Pola sidik jari loop banyak ditemukan pada jari kelingking.

\section{Bibliografi}

1. Limson K. S., Julian R. 2004. Computerized recording of the palatal rugae pattern and an evaluation of its application in forensic identification. Journal Forensic odontostomatol 22 : 1-4

2. Eboh E.O. Dennis. 2013. Fingerprint pattern in relation to gender and blood group among atudents of delta state uiversity, Abraka, Nigeria. Journal of experimental and crinical anatomy Nigeria 12 : 82-86

3. Eboh E.O. Dennis, and Nwjei M.O., 2012. Cheiloscopy in relation to ethnicity, gender and monozygotic twins in south-southern Nigeria. J Exp Clin Ana 11 (2): 1-7

4. Prakteek R., and Keerthi R. P. 2010. Study a of fingerprint in relation to gender and blood group. $J$ indian academy forensic med 32 (1): 11-4

5. Aarushi Jain, Arti Kalsulkar, and PA Mardikar. 2016 Study of relationship Between Thumbprint pattern and ABO Blood Groups. J Medical Sciences Panacea 6 (1) : 34-36

6. Vij K. 2005. Textbook of forensic medicine and Toxicology. 3 rd ed. Elsevier. New Delhi

7. Pillay V. V. 2009 . Text book of forensic medicine and toxicology. Paras medical Publishers. Hyderabad.

8. Manju S., Akhilesh T., and Isukapatla A. R. 2016.
Distribution of Fingerprint Pattern in Different $A B O$ Blood Groups. International Journal for Research in Emerging Science and Technology 3 (6): 94-100

9. Anonim. 2018. Red Cell Immunogenetics and Blood Group Terminology. http://www.isbtweb.org/workingparties/red-cell-immunogenetics-and-blood-groupterminology/. [di akses pada tanggal 30 Januari 2019]

10. Dean, Laura. 2005. Blood Groups and Red Cell Antigens. National Center for Biotechnology Information. US 